\title{
Organizational Culture Adaptability and SMEs Business Performance through Business Innovation
}

\author{
Badawi $^{1}$, Hm. Thamrin ${ }^{2}$, Priyo Susilo ${ }^{3}$ \\ \{Badawi@Umc.Ac.Id ${ }^{1}$ \} \\ ${ }^{1}$ muhammadiyah University Cirebon, Indonesia \\ ${ }^{2,3}$ muhammadiyah University Tangerang, Indonesia
}

\begin{abstract}
The aim of the study is to analyze the dimensions of cultural adaptability which consist of creating change, customer focus, and organizational learning and business innovation towards the performance of Culinary SMEs in West Java. The design of this research is causality research. The sampling technique in this study uses random sampling with a sample of 123 regional culinary SMEs in Kuningan Regency, Cirebon City, Majalengka, Indramayu and Cirebon Regency in West Java. Data collection methods used are sample research design surveys. The analysis technique is path analysis using the AMOS program of version 22. The results of this study indicate that two dimensions of cultural adaptability which consist of creating change and customer focus affect innovation and improve business performance both directly and indirectly. But the dimensions of organizational learning does not affect innovation and business performance either directly or indirectly. The results of this study also found that innovation mediates the effect of creating change and customer focus on performance. This study found that in order to create innovation and improve business performance requires change and focus on customers.
\end{abstract}

Keywords: Dimensions of cultural adaptability, innovation, business performance, and Regional Culinary SMEs

\section{Introduction}

A number of researchers argue that one of the factors that inhibit organizational success is the inability to adapt to learn with the environment (Jimmieson \& Griffiths, 2005; Lee., Tan, \& Chiu, 2008; Zheng, Yang, \& McLean, 2010). The inability to adapt to learn is not only comes from the individual concerned but also can be influenced by other factors such as the ability of cultural adaptability. Adaptability of organizational culture can be interpreted as the level of effectiveness of organizational culture in dealing with existing challenges and responding to changes that will be made (Wulandari et al, 2017). Organizational culture must be dynamic and adaptive to the organizational environment if the organization wants good performance for the long-term.

Several studies discuss cultural adaptability, innovation, and performance such as Dension \& Mishra (1995); Cengiz \& Ercan (2008) and Zhang et al., (2009), who examined the relationship between organizational culture components, including adaptability to innovation and business performance. Lumpkin and Dess (1996) on business performance. Wulandari et al (2017) examined the effect of organizational culture adaptability and motivation on employee commitment. Chan et al., (2004) stated that organizations are competitive advantages for sustainability and performance.

Some number of research results show the importance of cultural adaptability, innovation and performance relationships, Dension and Mishra (1995): Cengiz \& Ercan (2008) and Zhang et al, (2000) stated that the adaptability of organizational culture and innovation 
influences business performance. There are various benefits if companies can adapt to the organizational cultures, such as having the ability to compete (Denison, 1990). Furthermore, an effective adaptability of organizational culture can face different challenges by responding to various changes. In such situations, the readiness of all components of the organization is needed in facing the pressure from external environment. Lau and Ngo (2004) stated that organizational culture with development and innovation orientation has a direct influence on the company's innovation performance. Wulandari et al (2017) in the results of her research stated the adaptability of organizational culture and motivation influences organizational commitment

The purpose of this research is to solve the problem by analyzing the cultural adaptability dimension to the performance of SMEs through the creation of innovation. The reason for using this cultural adaptability is quite appropriate as the representation of SMEs' cultural adaptability in West Java is built through creating changes, customer focus and organizational learning towards business innovation and SME performance. This means that micro businesses need research that can improve performance by applying cultural adaptability to performance through the creation of innovation.

\section{Review Of Literature}

\subsection{Cultural Adaptability and Innovation}

An adaptive culture encourages and supports employees to improve their abilities by learning and everyday tasks (Denison et al, 2003). One of the components in cultural adaptability is organizational learning where organizations accept, translate, and interpret signals from the environment into opportunities to encourage innovation, acquire knowledge, and develop capabilities. Vakola and Rezgul (2000) stated that learning organization is seen as an opportunity for organizations to learn and improve, encourage innovation and risk-taking and guarantee knowledge and understanding of performance. The results of the research by Denison et al., (2003) stated that cultural adaptability besides influencing performance also influences innovation. The result of Keskin's (2006) study stated that learning orientation has a positive effect on innovation. Touminen et al (2002) that the component of cultural adaptability has a different and significant influence between high-performing and lowperforming companies in increasing innovation.

H1: Cultural adaptability to the dimensions of H1a creating change, H1b customer focus and H1c organizational learning can create SME business innovation

\subsection{Organizational Culture Adaptability and Performance}

Adaptability is one of the organizational cultures that focus on customers, the creation of change, and organizational learning. Organizations that have an adaptable culture tend to be both actively and openly accept and translate opportunities and threats from the external environment and respond to external signals appropriately (Pennington, 2003). Denison et al., (2008) in his study measured adaptability variables to three indexes, namely creating change, customer focus, and learning organization. Adaptable organizational culture can translate the demands of the organizational environment and into action, risk-taking, and learning from mistakes and having the capability and experience of creating change (Sange, 1990). Organizations that have adaptability usually experience sales growth and increase in market share (Denison \& Mishra, 1995) 
The results of the research by Ngo and Loi (2008) stated that the flexibility of human resources and organizational culture has a positive effect on business performance. According to Zhang et al, (2009) participatory culture can positively improve performance. Furthermore, adaptability culture and learning have a positive effect on performance. Yilmaz and Ercan (2008) stated that the four main characteristics of organizational culture; involvement, consistency, adaptability, and mission, have an influence on performance. Based on previous empirical studies, the hypothesis that is proposed is:

$\mathrm{H} 2$ : Cultural adaptability to the dimensions of $\mathrm{H} 2 \mathrm{a}$ creating change, $\mathrm{H} 2 \mathrm{~b}$ customer focus and

$\mathrm{H} 2 \mathrm{c}$ organizational learning can increase business performance

\subsection{The Role of Mediation Innovation in the adaptability of organizational culture and performance of SMEs}

According to Calantone et al, (2002) innovation is the openness of new ideas as an aspect of organizational culture with a willingness to try new ideas, find new ways to do things, be creative in operating methods and level of product recognition. A number of research results such as the research from Hult et al. (2004) stated that innovation has a positive effect on business performance. Prajogo (2006) study examined the relationship between innovation performance and business performance and compared between manufacturing and service companies. The results of his research shows that there is no significant difference between innovation in manufacturing and service companies. Lin and Chan (2007) research examined the nature and types of daily innovation practices. The results of the research shows that there is no difference between the nature and type of practice in daily innovation. The results of the study by Zhang et al (2009) stated that cultural adaptability has a positive influence on business performance. Based on the results of previous studies it can be concluded that the innovation variable plays the role of an enforcement variable that mediates the influence of adaptability variables and the dependent variable business performance.

H3: Innovation mediates the influence on cultural adaptability dimensions such as creating change, focusing on customers and organizational learning on and business performance.

\section{Research Methodology}

This research is a causality research for analysis purposes, the unit of analysis is an individual in each Regional Culinary SMEs. The sampling technique in this study used random sampling with a sample of 123 regional culinary SMEs in Kuningan Regency, Cirebon City, Majalengka, Indramayu, and Cirebon Regency in West Java. Data collection method used is sample research design surveys by collecting in one sample and at a point in time (Malhotra, 2004). Questionnaires were distributed to culinary SMEs in Kuningan District, Majalengka, Cirebon Regency, Cirebon City, and Indramayu. The measurement of variables in this study is adopted from; (1) Denison et al., (2008) for cultural adaptability variables, consisting of three dimensions, namely (a) Creating change, (b) Focusing on customers, and (c) Organizational Learning with fifteen (15) statement items. Prajogo (2009) for innovation variables with three (3) statement items. Lee and Tsang (2001) for business performance variables with three (3) statement items. The scale technique used is a Likert scale ranging from 1 (strongly disagree) to 5 (strongly agree). Statistical techniques using Path analysis with AMOS 22. The results of the validity and reliability tests found are valid and reliable. 


\subsection{Data Analysis}

The profiles of respondents were mostly male types of 72.36 and women at $27.64 \%$. The respondent's age is $20-35$ years $(32.58 \%)$ ) 35 - 45 years $(44.7 \%)$, and $>45$ years $(31.7 \%)$. Education of elementary school respondents (18\%) junior high school (38\%) high school $(43 \%)$ and college $(9.7 \%)$. Duration of business $1-10$ years $(16.2 \%) 11-20$ years $(47.1 \%),>21$ years $(49.5 \%)$

Figure 1 shows the result of path analysis data processing with the help of the 22-version AMOS software to test the causal relationship between the constructs used in the hypothesized path model. Structural model testing generallyresults in a fit indices model.

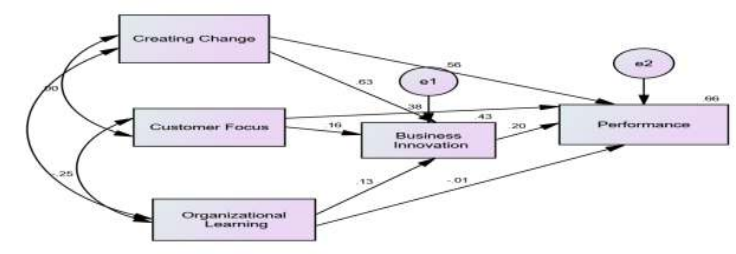

Fig.1. Diagram Of The Results Of The Path Model

Tabel 1. The Influence of Dependent and Independent Variable

\begin{tabular}{lllllll}
\hline \multicolumn{2}{l}{ Relationships Between Variables } & $\begin{array}{l}\text { Standardi } \\
\text { zed }\end{array}$ & $\begin{array}{l}\text { Unstandardi } \\
\text { zed }\end{array}$ & $\begin{array}{l}\text { P_val } \\
\text { ue }\end{array}$ & Notes \\
\hline H1a & Creating Change & $\begin{array}{l}\text { Business } \\
\text { Innovation }\end{array}$ & 0.631 & 9.240 & $* * *$ & Significant \\
\hline H1b & Customer Focus & $\begin{array}{l}\text { Business } \\
\text { Innovation }\end{array}$ & 0.165 & 2.334 & 0.020 & Significant \\
\hline H1c & $\begin{array}{l}\text { Organizational } \\
\text { Learning }\end{array}$ & $\begin{array}{l}\text { Business } \\
\text { Innovation }\end{array}$ & 0.132 & 1.876 & 0.061 & $\begin{array}{l}\text { Not } \\
\text { Significant }\end{array}$ \\
\hline H2 & Innovation & Performance & 0.199 & 2.862 & 0.004 & Significant \\
\hline H3a & Creating Change & Performance & 0.560 & 8.180 & $* * *$ & Significant \\
\hline H3b & Customer Focus & Performance & 0.382 & 6.885 & $* * *$ & Significant \\
\hline H3c & $\begin{array}{l}\text { Organizational } \\
\text { Learning }\end{array}$ & Performance & 0.008 & 0.154 & 0.877 & $\begin{array}{l}\text { Not } \\
\text { Significant }\end{array}$ \\
\hline
\end{tabular}

Table 1. There are seven testing hypotheses proposed. H1a: Creating changes influences business innovation with the $\beta$ value of 0.631 or P-value of $0.000<0.05$. H1b: Customer focus has an effect on business innovation with $\beta$ value 0.165 or P-value $0.020<0.05 \mathrm{H} 1 \mathrm{c}$ : Organizational learning has no effect on innovation with $\beta$ value 0.134 or P-value $0.061>$ 0.05 . H2: Innovation influences business performance with $\beta$ value 0.199 or P-value 0.004 $<0.05$. H3a: Creating a change has an effect on Performance with a value of $\beta 0,506$ or Pvalue $0,000<0,05$. H3b: Customer focus has an effect on Performance with a value of $\beta 0.382$ 
or P-value $0.000<0.05$. H3c: Organizational learning has no effect performance with a value of $\beta 0.008$ or $\mathrm{P}$-value $0.877>0.05$.

Tabel 2. Indirect Effect and Total Effect on Dimensions of Cultural Adaptability, Innovation and Business Performance

\begin{tabular}{llllll}
\hline $\begin{array}{l}\text { Independent } \\
\text { Variables }\end{array}$ & $\begin{array}{l}\text { Mediator } \\
\text { Variable }\end{array}$ & $\begin{array}{l}\text { Dependent } \\
\text { Variables }\end{array}$ & $\begin{array}{l}\text { Indirect } \\
\text { Effect }\end{array}$ & $\begin{array}{l}\text { Total } \\
\text { Effect }\end{array}$ & $\begin{array}{l}\text { P- } \\
\text { Value }\end{array}$ \\
\hline Creating Change & $\begin{array}{l}\text { Business } \\
\text { Innovation }\end{array}$ & Performance & 0.125 & 0.686 & 0.000 \\
& $\begin{array}{l}\text { Business } \\
\text { Innovation }\end{array}$ & Performance & 0.030 & 0.415 & 0.000 \\
\hline Customer Focus & $\begin{array}{l}\text { Business } \\
\text { Innovation }\end{array}$ & Performance & 0.026 & 0.018 & 0.199 \\
\hline $\begin{array}{l}\text { Organizational } \\
\text { Learning }\end{array}$ & & & & & \\
\hline
\end{tabular}

Table 2. Shows that innovation mediates the effect of creating change and customer focus on performance with a total value of 0.686 or P-value $0.000<0.05$ and 0.415 or P-value $0,000<0.05$. But innovation has no mediate the effect of organizational learning on performance with a total value of 0.018 or P-value $0.199>0.05$.

\subsection{Discussion}

The model results in Figure 1 and Table 1 show some findings that cultural adaptability in the dimension of creating change, and customer focus can create business innovation, which means that $\mathrm{H} 1$ and $\mathrm{H} 2$ are accepted. These findings illustrate that there is a significant influence between creating change and customer focus with innovation, where cultural adaptability in the dimension of creating change and customer focus is one level of adaptability. These findings also position that an adaptive organization in responding to external demands actively can creates change and is able to face obstacles to find ways to overcome them. The application of adaptive culture can be seen as feedback and learning to respond to demands from the external environment. The results of this study are in line with the findings of Ashley and Bryan, (2009) that organizational culture is positively related to innovation. The results of this study also strengthen the results of the study of Denison et al., (2003) which stated that cultural adaptability besides influencing performance also affects innovation.

Unfortunately, in the results of this study cultural adaptability in the dimension of organizational learning cannot create business innovation. These findings are in contrary to the findings of Vakola \& Rezgul (2000) who stated that learning organization is seen as an opportunity for organizations to learn and improve, encourage innovation and risk-taking, ensure knowledge transfer, and understand performance. The results of this study illustrate that the organizational learning orientation of SMEs is actually still very low, they assume that learning is not considered as top priority, because the learning process is still perceived as a habit.

Table 1 shows the findings that cultural adaptability in the dimension of creating change and customer focus has an effect on business performance. The results of this study reinforce the findings of Denison et al., (2008), and Zhang et al., (2009) who concluded that cultural adaptability influences business performance. Adaptability measures a company's ability to read and scan the business environment and to respond to change (Denison et al., (2003) 
The results of this study in Table 2. shows that innovation mediates the effect of creating change and customer focus on business performance. This means that a positive role of innovation can improve performance and profitability, size, market share, and growth rate. These findings are in line with the results of Salavou (2003) that business innovation is the most important determinant of performance when it seen from the level of ROA. The results of Prajogo's research (2006) stated that there is a positive relationship between innovation performance and business performance.

Among the findings of this study, only the adaptability variables of organizational learning have no effect on innovation, and performance either directly or through the mediation of innovation. Thus, these results are not in line with previous research, which finds cultural adaptability to the dimensions of organizational learning positively related to innovation (Ashley and Bryan, 2009). One explanation is that the longer the SMEs feel successful from their efforts, the higher their sense of ego does not feel important to learn which implicitly changes the psychological contract (Kolb, 1998).

In accordance with the results of the study, it turns out that many organizations, especially SMEs can benefit from implementing cultural adaptability which consists of creating change, customer focus and organizational learning in supporting the creation of business innovation. Three dimensions of cultural adaptability can be improved through various models and approaches, especially in the dimensions of organizational learning in creating innovation and performance in Culinary SMEs in West Java, Indonesia. For practitioners in organizational development, especially in the dimensions of organizational learning in Culinary SMEs that are not familiar with organizational learning is very difficult to overcome, especially when the focus of change involves changes in processes, policies, and technologies that will see changes in SME behavior.

This study contributes to the research by applying the cultural adaptability dimension model to better understand the relationship between the dimensions of cultural adaptability consisting of creating change, customer focus, and organizational learning through business innovation that has an impact on business performance. This study helps Culinary SMEs not only to understand the dimensions of cultural adaptability consisting of creating change, customer focus and organizational learning to implement effective strategies, and improving innovation skills, but also to further strengthen their competitiveness that is successful in the market

\section{Conclusions}

The results of this study indicate that cultural adaptability which consists of creating dimensions and customer focus can create innovation and improve performance both directly and indirectly. The role of innovation can mediate the influence of cultural adaptability which consists of creating dimensions of change and customer focus on business performance. But cultural adaptability to the dimensions of organizational learning cannot create innovation and improve business performance. Furthermore, the role of innovation does not mediate the influence of cultural adaptability on the dimensions of organizational learning on business performance.

Some opportunities for future research need to consider the addition of indicators to learning orientation variables by using a structural analysis technique model and understanding the influence of cultural types on the ability to innovate. 


\section{References}

[1] Ashley, G. M. and Bryan, A. (2009) Organizational culture and innovation: exploring the link, " 11th Annual Best of Organizational Development Summit.

[2] Calantone, R. ., Cavusgil, S. and Zhao Yushan (2002) 'Innovation and learning in the knowledge -based economy, challenges for the firm', International Journal of Technology Management, 43, pp. 531-533.

[3] Chan. L. Shaffer MA and Snape, E. (2004) 'In search of susitained comperative advantage: the impact of organization culture, competitive strategy and human resource management practice on firm performance', Int J. Human. Res, Manage, p. 35.

[4] Denison, D. R. and Mishra, A. K. (1995) Toward a theory of organizational culture and effectiveness.

[5] Denison, D. (2018) 'Corporate culture and organizational effectiveness : Is there a similar pattern around the world?', 1203(April 2003). doi: 10.1016/S15351203(02)03011-3.

[6] Denison, D. R., Haaland, S. and Goelzer, P. (2003) 'CORPORATE CULTURE AND ORGANIZATIONAL EFFECTIVENESS: IS THERE A SIMILAR PATTERN AROUND THE WORLD?', in, pp. 205-227. doi: 10.1016/S1535-1203(02)03011-3.

[7] Hult, G. T. M., Hurley, R. F. and Knight, G. A. (2004) 'Innovativeness: Its antecedents and impact on business performance', Industrial Marketing Management. Elsevier, 33(5), pp. 429-438. doi: 10.1016/J.INDMARMAN.2003.08.015.

[8] Keskin, H. (2006) 'Market orientation, learning orientation, and innovation capabilities in SMEs', European Journal of Innovation Management, 9(4), pp. 396-417. doi: $10.1108 / 14601060610707849$.

[9] Lau, C. and Ngo, H. (2004) 'The HR system, organizational culture, and product innovation', International Business Review. Pergamon, 13(6), pp. 685-703. doi: 10.1016/J.IBUSREV.2004.08.001.

[10] Lee, C. K., Tan, B. and Chiu, J. Z. (2008) 'The impact of organisational culture and learning on innovation performance', International Journal of Innovation and Learning, 5(4).

[11] Lumpkin, G. . and Dess, G. . (1996) 'Clarify the EO Construct and Linking it to Performance', Academy of Management Review, 21.

[12] Malhotra, N. K. (2007) 'Review of Marketing Research', in, pp. v-v. doi: 10.1108/S1548-6435(2007)0000003004.

[13] Ngo, H. Y. and Loi, R. (2008) 'Human resource flexibility, organizational culture and firm performance: an invest igation of multinational firms in Hong Kong', the international journal of human resource management, 19(9), pp. 1654-1666. doi: https://doi.org/10.1080/09585190802295082

[14] Pennington, G. (2003) Guidelines for Promoting and Facilitating Change. LTSN Generic Centre. Available at: http;//jiscifonet.ac.uk/infokis/change management/lessons he sector.

[15] Prajogo, D. I. (2006) 'Relationship between Innovation and Business Performance -A Comperative Study between Manufacturing and Service Firms', Knowladge and Process Management, 13, pp. 218-225.

[16] Salavou, H. and Lioukas, S. (2003) 'Radical Product Innovation in SMEs: The Dominance of Entrepreneurial Orientation, creativity and Innovation Managemen', journal recommondation service, 12(2), pp. 94-106.

[17] Touminen, M. and Rajala, A. M. (2002) 'How does adaptability drive firm 
innovationess?', Journal of Business Research, 57(5), pp. 495-506.

[18] Vakola, M. and Rezgui, Y. (2000) 'Organisational learning and innovation in the construction industry', The Learning Organization, 7(4), pp. 174-184. doi: 10.1108/09696470010342324.

[19] Wulandary. T. Syamsun, M. and Dirjosuparto, S. (2017) Pengaruh Adaptabilitas Budaya Organisasi dan Motivasi terhadap Komitmen Karyawan pada Organisasi PT KraKatau steel Tbk.

[20] Yeh - Yun Lin, C. and Yi - Ching Chen, M. (2007) 'Does innovation lead to performance? An empirical study of SMEs in Taiwan', Management Research News, 30(2), pp. 115-132. doi: 10.1108/01409170710722955.

[21] Yilmaz, C. and Ergun, E. (2008) 'Organizational culture and firm effectiveness: An examination of relative effects of culture traits and the balanced culture hypothesis in an emerging economy', Journal of World Business. JAI, 43(3), pp. 290-306. doi: 10.1016/J.JWB.2008.03.019.

[22] Zhang, Y., Li Xia and Pan Feng (2009) 'The Relationship between Organization Culture and Govermment Performance on Dension Model', Asian Social Science, $5(11)$.

[23] Zheng, W., Yang, B. and McLean, G. N. (2010) 'Linking organizational culture, structure, strategy, and organizational effectiveness: Mediating role of knowledge management', Journal of Business Research. Elsevier, 63(7), pp. 763-771. doi: 10.1016/J.JBUSRES.2009.06.005. 